\title{
Biochemical, Microbiological and Organoleptic Properties of Probiotic Pineapple Juice Developed by Lactic Acid Bacteria
}

\author{
M. A. Hossain ${ }^{1 *}$, M. M. Hoque ${ }^{1}$, M. M. Hossain ${ }^{1}$, M. H. Kabir ${ }^{1}$, M. Yasin ${ }^{1}$, M. A. Islam² \\ ${ }^{1}$ Department of Food Engineering and Tea Technology, Shahjalal University of Science and \\ Technology, Sylhet-3114, Bangladesh \\ ${ }^{2}$ Department of Food Science \& Technology, Sunchon National University, South Korea
}

Received 28 March 2020, accepted in final revised form 25 May 2020

\begin{abstract}
An experiment was undertaken to determine the suitability of pineapple juices as raw materials for the production of fermented probiotic juice by two lactic acid bacteria, Lactobacillus plantarum and Lactobacillus fermentum. Three probiotic juice samples inoculated with $L$. plantarum (S-2), L. fermentum (S-3) and with both $L$. plantarum and $L$. fermentum (S-4) were compared with that of control sample (S-1) where no Lactobacillus strains were used. Fermentation was carried out at $37^{\circ} \mathrm{C}$ for $48 \mathrm{~h}$. Then the juice samples were stored at $4{ }^{\circ} \mathrm{C}$ and studied the change in their physicochemical properties at day 0,7 , 14 and 21 . Both $L$. plantarum and $L$. fermentum were able to withstand and utilize fruit juices for their cell synthesis as indicated by a decrease in fruit sugar and an increase in acidity. Although the lactic cultures in fermented probiotic juices gradually lost their viability, the viable cell counts of these strains remained at $10^{7} \mathrm{CFU} / 100 \mathrm{~mL}$ after 14 days in cold storage. From sensory evaluation, the juice sample prepared with $L$. plantarum exhibits the best result during storage time. Hence, pineapple juice might be used as a suitable medium for the production of a healthy probiotic beverage.
\end{abstract}

Keywords: Lactobacillus fermentum; Lactobacillus plantarum; Pineapple juice, Probiotification; Quality evaluation.

(C) 2020 JSR Publications. ISSN: 2070-0237 (Print); 2070-0245 (Online). All rights reserved. doi: http://dx.doi.org/10.3329/jsr.v12i4.46179

J. Sci. Res. 12 (4), 743-750 (2020)

\section{Introduction}

Probiotics are live microbial feed supplements. They can enhance the health of consumer by improving the balance of micro flora in the gut when ingested live in sufficient numbers [1]. The consumption and development of probiotic foods is increasing day by day due to the consumer awareness about functional foods, of which has ability to maintain good health. The role of probiotic organisms as complementary therapy in combating large number of gastrointestinal disorders and their ability to enhance immune response attracts global attention. Probiotic microorganisms are claimed to provide

${ }^{*}$ Corresponding author: mahossain-fet@ sust.edu 
several health benefits, including antimicrobial, anti-tumor, anti-cholesterol, immunomodulation, anti-diabetic, and treatment of diarrhea and lactose intolerance [2-6].

Nowadays probiotics consumption through dairy-based beverages such as milk, yogurt and cheese are very popular, as they are excellent carrier. Because of fear of mycotoxins in fruits and vegetables [7], the use of microorganisms in plant based food is still very low. Consequently, the potential applications of probiotics in non-dairy food products for vegetarian, yet not received formal recognition. On the other hand, consumer demand for non-dairy based probiotic products has increased due to the problems of lactose intolerance and cholesterol content associated with the consumption of fermented dairy products [8]. In this respect, fruit juice offers an alternative to produce probiotic foods using Lactobacillus species as some Lactobacillus species were found to have the capacity to reduce blood cholesterol levels $[9,10]$.

Different studies have been carried out to explore the suitability of vegetable juices such as tomato, beet and cabbage as raw materials to produce probiotic drinks using $L$. plantarum, L. acidophilus and L. casei. Results have indicated that all the strains can grow in the fruit juices and microbial population increases significantly after $48 \mathrm{~h}$ of fermentation [11-15]. In this context, an effort was made to develop pineapple juice with potential probiotic Lactobacillus isolates and investigate their physicochemical and microbial stability during storage at $4{ }^{\circ} \mathrm{C}$ to ensure better health and nutrition of the population upon consumption.

\section{Materials and Methods}

\subsection{Collection of Lactobacillus strains}

Two Lactobacillus isolates viz. Lactobacillus plantarum DSM 10492 and Lactobacillus fermentum DSM 20052 were collected from the Deutsche Sammlung von Mikroorganismen und Zellkulturen $\mathrm{GmbH}$, Germany. Both lactobacillus cultures were kept at $-20{ }^{\circ} \mathrm{C}$ in MRS medium (Merck, Germany) containing $20 \%$ glycerol. Before probiotic juice preparation, these isolates were selected after performing different potential probiotic confirmation tests like: $\mathrm{NaCl}$ tolerance test (1-8\%), $\mathrm{pH}(2.5$ to 6.5$)$ and bile salt tolerance test $(0.05-0.25 \%)$ as well as antimicrobial, antibiotic susceptibility and growth test at stressful mixed (low $\mathrm{pH}$, high bile and $\mathrm{NaCl}$ ) conditions and used for probiotic pineapple fruit juices development.

\subsection{Pineapple juice preparation, inoculation and fermentation}

Fresh pineapple juice was prepared by juice extractor. Extracted juice was pasteurized at $80{ }^{\circ} \mathrm{C}$ for $5 \mathrm{~min}$ [16]. The lactic cultures were first grown in MRS broth at $37^{\circ} \mathrm{C}$ for $48 \mathrm{~h}$. After cooling the pineapple juice at $30{ }^{\circ} \mathrm{C}$ they were inoculated by $1 \%$ L. plantarum (S2), $1 \%$ L, fermentum (S-3), and their mixed (0.5\% each) culture (S-4). Fresh pineapple juice sample was used as control (S-1).The inoculated samples along with control samples were incubated at $37^{\circ} \mathrm{C}$ for $48 \mathrm{~h}$. 


\subsection{Physicochemical and microbiological assay}

After fermentation, all the samples were stored at $4{ }^{\circ} \mathrm{C}$. Then physicochemical parameters, such as, titratable acidity (expressed as percent lactic acid), moisture, protein, total soluble solid (TSS) contents, and total sugar content were evaluated to check the physicochemical stability of pineapple juice during storage period. The sugar content was estimated in terms of glucose $(\mathrm{mg} / \mathrm{mL})$ by the phenol sulfuric acid method [17]. Protein and moisture content was determined according to the AOAC [18]. Total soluble solid (TSS) were measured by a hand refractometer as percent $(\%)$ degree Brix.

Viable cell counts $(\mathrm{CFU} / \mathrm{mL})$ was determined by the standard plate count (SPC) method using MRS agar [19]. All Physicochemical and microbiological status of the treated juices were monitored up to 21 days at 7 days interval during storage period.

\subsection{Sensory evaluation}

Thirty tasters were used in this study to assess the sensory properties of produced probiotic juice samples [20]. The panelists were asked to rate different juice samples present in them. Water and bread were provided to panel members to cleanse their palates between samples. In this case, 9 point hedonic rating test was performed to assess the degree of acceptability of these juices as follows: (9=Like extremely, $8=$ Like very much, 7=Like moderately, 6=Like slightly, 5=Neither like or dislike, 4=Dislike slightly, 3=Dislike moderately, 2=Dislike very much, 1=Dislike extremely).

\subsection{Statistical analysis}

All results of this study are reported as mean of three replicates that were analyzed. One way analysis of variance (ANOVA) and Duncan's Multiple Range Test (DMRT) for all physicochemical analysis were determined by using SPSS (Statistical Package for the Social Science, version 20, copyright of IBM Corporation and others) software [21]. The least significant difference was calculated at $95 \%$ level of significance $(\mathrm{P}<0.05)$.

\section{Results}

\subsection{Physicochemical analysis of juice samples}

The Physiochemical conditions of pineapple juice during storage period are presented in Table 1. In case of control sample (S-1) the values of acidity, moisture, protein content, total sugar content, and TSS were differed slightly throughout the storage days (Table 1). Acidity was increased from $0.191 \pm 0.005$ to $0.243 \pm 0.008$ after 21 days of storage. Total soluble solid as indicated by ${ }^{\circ} \mathrm{Bx}$ was reduced from $20.167 \pm 0.289$ to $18.333 \pm 0.289$. Total sugar $(\mathrm{mg} / 100 \mathrm{~mL})$ content was also slightly declined during storage. 
Table 1. Physiochemical analysis of pineapple juice.

\begin{tabular}{ccccccc}
\hline $\begin{array}{c}\text { Sample } \\
\text { No. }\end{array}$ & Day & $\begin{array}{c}\text { Acidity (\% of } \\
\text { lactic acid) }\end{array}$ & Moisture (\%) & Protein (\%) & $\begin{array}{c}\text { Total sugar } \\
(\mathrm{mg} / 100 \mathrm{~mL})\end{array}$ & $\begin{array}{c}\text { Total soluble } \\
\left.\text { solid ( }{ }^{\circ} \mathrm{Bx}\right)\end{array}$ \\
\hline & 0 & $0.191 \pm 0.005^{\mathrm{D}}$ & $72.680 \pm 0.026^{\mathrm{A}}$ & $0.432 \pm 0.007^{\mathrm{A}}$ & $175.237 \pm 0.251^{\mathrm{D}}$ & $20.167 \pm 0.289^{\mathrm{C}}$ \\
$\mathrm{S}-1$ & 7 & $0.203 \pm 0.008^{\mathrm{C}}$ & $72.973 \pm 0.021^{\mathrm{B}}$ & $0.430 \pm 0.006^{\mathrm{A}}$ & $173.500 \pm 0.500^{\mathrm{C}}$ & $19.167 \pm 0.289^{\mathrm{B}}$ \\
& 14 & $0.227 \pm 0.005^{\mathrm{B}}$ & $73.200 \pm 0.050^{\mathrm{C}}$ & $0.432 \pm 0.006^{\mathrm{A}}$ & $169.403 \pm 0.364^{\mathrm{B}}$ & $18.333 \pm 0.289^{\mathrm{A}}$ \\
& 21 & $0.243 \pm 0.008^{\mathrm{A}}$ & $73.637 \pm 0.045^{\mathrm{D}}$ & $0.415 \pm 0.017^{\mathrm{A}}$ & $167.006 \pm 0.500^{\mathrm{A}}$ & $18.333 \pm 0.289^{\mathrm{A}}$ \\
\hline \multirow{4}{*}{$\mathrm{S}-2$} & 0 & $0.316 \pm 0.005^{\mathrm{D}}$ & $70.843 \pm 0.040^{\mathrm{A}}$ & $0.453 \pm 0.009^{\mathrm{C}}$ & $182.037 \pm 0.158^{\mathrm{D}}$ & $20.167 \pm 0.289^{\mathrm{D}}$ \\
& 7 & $0.379 \pm 0.007^{\mathrm{C}}$ & $71.040 \pm 0.046^{\mathrm{B}}$ & $0.434 \pm 0.008^{\mathrm{B}}$ & $178.387 \pm 0.287^{\mathrm{C}}$ & $19.000 \pm 0.000^{\mathrm{C}}$ \\
& 14 & $0.423 \pm 0.008^{\mathrm{B}}$ & $71.400 \pm 0.050^{\mathrm{C}}$ & $0.424 \pm 0.005^{\mathrm{B}}$ & $175.170 \pm 0.725^{\mathrm{B}}$ & $17.333 \pm 0.289^{\mathrm{B}}$ \\
& 21 & $0.442 \pm 0.003^{\mathrm{A}}$ & $72.047 \pm 0.015^{\mathrm{D}}$ & $0.410 \pm 0.005^{\mathrm{A}}$ & $170.390 \pm 0.610^{\mathrm{A}}$ & $16.167 \pm 0.289^{\mathrm{A}}$ \\
\hline \multirow{4}{*}{$\mathrm{S}-3$} & 0 & $0.212 \pm 0.009^{\mathrm{D}}$ & $70.543 \pm 0.040^{\mathrm{A}}$ & $0.443 \pm 0.009^{\mathrm{B}}$ & $144.500 \pm 0.500^{\mathrm{D}}$ & $20.167 \pm 0.289^{\mathrm{D}}$ \\
& 7 & $0.299 \pm 0.009^{\mathrm{C}}$ & $71.057 \pm 0.025^{\mathrm{B}}$ & $0.426 \pm 0.005^{\mathrm{A}}$ & $143.537 \pm 0.223^{\mathrm{C}}$ & $19.333 \pm 0.289^{\mathrm{C}}$ \\
& 14 & $0.354 \pm .004^{\mathrm{B}}$ & $71.663 \pm 0.032^{\mathrm{C}}$ & $0.424 \pm 0.011^{\mathrm{A}}$ & $142.380 \pm 0.336^{\mathrm{B}}$ & $18.000 \pm 0.000^{\mathrm{B}}$ \\
& 21 & $0.389 \pm 0.009^{\mathrm{A}}$ & $72.127 \pm 0.030^{\mathrm{D}}$ & $0.423 \pm 0.007^{\mathrm{A}}$ & $141.493 \pm 0.490^{\mathrm{A}}$ & $17.333 \pm 0.289^{\mathrm{A}}$ \\
\hline \multirow{4}{*}{$\mathrm{S}-4$} & 0 & $0.282 \pm 0.008^{\mathrm{D}}$ & $70.550 \pm 0.100^{\mathrm{A}}$ & $0.445 \pm 0.008^{\mathrm{C}}$ & $180.173 \pm 0.158^{\mathrm{D}}$ & $20.167 \pm 0.289^{\mathrm{D}}$ \\
& 7 & $0.322 \pm 0.007^{\mathrm{C}}$ & $72.623 \pm 0.309^{\mathrm{B}}$ & $0.434 \pm 0.005^{\mathrm{BC}}$ & $177.510 \pm 0.234^{\mathrm{C}}$ & $19.667 \pm 0.289^{\mathrm{C}}$ \\
& 14 & $0.351 \pm 0.005^{\mathrm{B}}$ & $74.533 \pm 0.038^{\mathrm{C}}$ & $0.428 \pm 0.005^{\mathrm{AB}}$ & $173.060 \pm 0.010^{\mathrm{B}}$ & $19.000 \pm 0.000^{\mathrm{B}}$ \\
& 21 & $0.387 \pm 0.005^{\mathrm{A}}$ & $75.087 \pm 0.040^{\mathrm{D}}$ & $0.422 \pm 0.010^{\mathrm{A}}$ & $168.386 \pm 0.280^{\mathrm{A}}$ & $18.333 \pm 0.289^{\mathrm{A}}$ \\
\hline
\end{tabular}

*Means and standard deviations for $\mathrm{n}=3$. The experimental values within columns of individual sample that have no common superscript are significantly different $(P<0.05)$ according to Duncan's multiple range test (DMRT).

The physicochemical changes of probiotic pineapple juice prepared by L. plantarum (S-2) at chill storage are presented in Table 1 (S-2). There were general increase in the acidity and moisture content throughout the storage days which resulted from the production of lactic acid. However, the value of protein content, total sugar content, and TSS were decreased with time. Though protein content did not show any significant difference $(\mathrm{p}<0.05)$, but TSS and total sugar content showed significant difference at different days.

These changes are almost same in case of sample 3 where L. fermentum was used as probiotic bacteria. Table 1 (S-3) shows the changes in acidity, moisture, protein content, total sugar content, and TSS of probiotic pineapple juice prepared by L. fermentum. It was found that $L$. fermentum produce lower amount of lactic acid $(0.212 \pm 0.009 \%$ at day 0 to $0.389 \pm 0.009 \%$ at day 21$)$ in contrast with L. plantarum $(0.316 \pm 0.005 \%$ at day 0 to $0.442 \pm 0.003 \%$ at day 21 ).

Sample 4 was prepared by equal amount of both L. plantarum and L. fermentum ( $0.5 \%$ of each). Like other probiotic juice samples, the protein content, total sugar content and TSS were decreased with time whereas the acidity and moisture percentage showed upward trends at refrigerated storage condition. Interestingly, total sugar content was somewhat higher in sample $4(180.173 \pm 0.158 \mathrm{mg} / 100 \mathrm{~mL}$ at day 0 to $168.386 \pm 0.280$ $\mathrm{mg} / 100 \mathrm{~mL}$ at day 21), but other parameters were almost same as in sample 1, 2 and 3 . All parameters showed significant changes $(\mathrm{p}<0.05)$ throughout the chilled storage days. 


\subsection{Microbiological assay}

The growth and viability of Lactobacillus culture in juice samples were studied and presented in Table 2. The lactobacillus counts of $1 \mathrm{~mL}$ of starter cultures were measured by growing the pure isolates in MRS broth for $48 \mathrm{~h}$ at $37^{\circ} \mathrm{C}$. Initially, L. fermentum grows well in broth culture and exhibited the highest count. L. plantarum and L. fermentum are grown well individually, as well as in mixed state in pasteurized pineapple juice during fermentation without the addition of any other external nutrient. The lactic cultures were able to withstand and reproduce in all three probiotic juice samples. For example, $L$. plantarum (in S-2) count was increased from $5 \pm 0.13 \times 10^{6}$ at starter culture to $1.23 \pm 0.54 \times 10^{9}$ at day 0 . This count was increased slightly at day $7\left(1.37 \pm 0.48 \times 10^{9}\right)$. But afterwards, they started losing their viability. The count $\left(1.07 \pm 0.39 \times 10^{8}\right)$ was well above standard up to day 14 . However, the count was reduced to $8.33 \pm 0.56 \times 10^{6}$ at day 21 . This trend was almost similar for sample 2 and 3. No Lactobacillus strain was found in control sample.

Table 2. Changes in the viability of L. plantarum and L. fermentumin refrigerated probiotic pineapple juice.

\begin{tabular}{lccc}
\hline \multirow{2}{*}{ Day } & \multicolumn{3}{c}{ CFU/mL } \\
\cline { 2 - 4 } & $\begin{array}{c}\text { L. plantarum } \\
(\mathrm{S}-2)\end{array}$ & $\begin{array}{c}\text { L. fermentum } \\
(\mathrm{S}-3)\end{array}$ & $\begin{array}{c}\text { Mixed culture of } \text { L. plantarum } \\
\text { and } L \text {. fermentum }(\mathrm{S}-4)\end{array}$ \\
\hline Starter culture & $5 \pm 0.13 \times 10^{6}$ & $1.63 \pm 0.41 \times 10^{7}$ & $1.1 \pm 0.62 \times 10^{7}$ \\
0 & $1.23 \pm 0.54 \times 10^{9}$ & $1.57 \pm 0.66 \times 10^{9}$ & $1.03 \pm 0.37 \times 10^{9}$ \\
7 & $1.37 \pm 0.48 \times 10^{9}$ & $1.73 \pm 0.74 \times 10^{9}$ & $1.17 \pm 0.54 \times 10^{9}$ \\
14 & $1.07 \pm 0.39 \times 10^{8}$ & $1.23 \pm 0.72 \times 10^{8}$ & $1.01 \pm 0.29 \times 10^{8}$ \\
21 & $8.33 \pm 0.56 \times 10^{6}$ & $9.67 \pm 0.37 \times 10^{6}$ & $9.33 \pm 0.42 \times 10^{6}$ \\
\hline
\end{tabular}

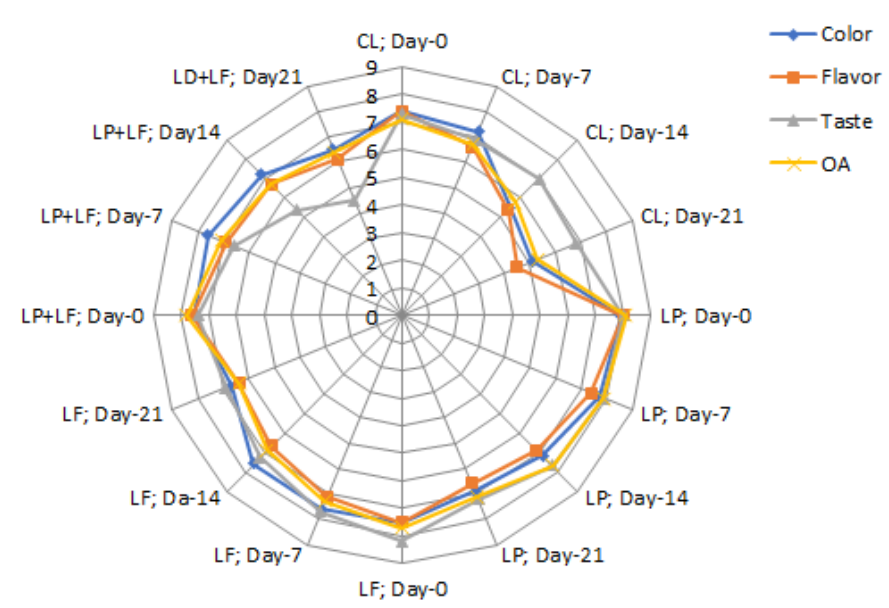

Fig. 1. Sensory profiles of pineapple juice produced by fermentation with $L$. plantarum, $L$. fermentum and their mixed culture. $\mathrm{LP}=L$. plantarum, $\mathrm{LF}=L$. fermentum, $\mathrm{CL}=\mathrm{Control}, \mathrm{OA}=$ Overall acceptability. 
Sensory profiles of pineapple juice produced by fermentation with of L. plantarum, $L$. fermentum and their mixed culture are presented in Fig. 1. The sensory scores of control sample were reduced drastically at long storage. Taste of the mixed culture inoculated juice showed poor results than L. plantarum and L. fermentum inoculated juice. Color and flavor scores also showed similar results. Overall acceptability of L. plantarum (S-2) inoculated juice was quite consistent than others.

\section{Discussion}

This study was aimed to make probiotic pineapple juice and to check whether probiotic pineapple juice could show a significant difference in physiochemical parameter or in microbial population during storage.

The acidity of all the fermented samples during storage period was low and varied a little, among different days (Table 1). This acidic condition could lead to the decrease in the maximum growth rate and an extended length of the lag phase. During this period metabolic activity and lactic acid production is minor and the bacterial cells tried to adapt with the new conditions. Therefore, in this study, acidity of probiotic juices increases with time. Yoon [22] also found an increased acidity when tomato juice was inoculated with $L$. delbrueckii, L. acidophilus, L. plantarum and L. casei.

The moisture content of all the treated samples was slightly increased with time. This may be due to the use of dry matter by bacteria for their metabolism. Increased moisture content reduces the nutritive factors such as fat, protein and carbohydrate, thereby reducing the energy value. It means moisture content and energy values are reversely correlated. Our findings also found similarities with Nazarudeen [23].

In this study, the protein content of pineapple juice was not varied so much (reduced very slowly) but total sugar content and total soluble solid (TSS) were decreased with time. It is anticipated that bacterial cells use those total available sugars and total soluble solid as food. As a result, total sugar and TSS content were decreased gradually [16,2226]. This may be due to bacterial cell was capable of growing in fruit juice without additional nutrient supplement.

Microbial viability is the most important factor during storage period. Here, Lactobacillus culture viability increased with time up to seven days and then decreased gradually (Table 2). The results indicated that both L. plantarum and L. fermentum were able to withstand and utilized fruit juices for their cell synthesis, as indicated by a decrease in fruit sugar and an increase in acidity. After one week, Lactobacillus population started to reduce. Juice inoculated with $L$. fermentum showed the best performance in terms of population density than other samples. The total count of Lactobacillus for all probiotic pineapple juice samples were well above the standard value $\left(10^{7}\right)$ up to day 14 . This high viable count is important for maximum health benefits by probiotic foods [27]. This result agrees with the report of Hossain et al. and Gaanappriya et al. $[28,29]$, who stated that probiotic pineapple juice could be considered as a probiotic beverage without any nutritional supplement. The growth of these probiotic bacteria could have been affected by various factors such as availability of oxygen, fermentation time 
and storage temperature [30,31]. It has been also reported that the acid production ability of lactic acid bacteria, especially post incubation (post-acidification) affects the cell viability of probiotic bacteria, including L. acidophilus and Bifidobacterium bifidum [32, 33].

The results of hedonic tests reflect that the color, flavor, taste and overall acceptability of probiotic pineapple juice were preferred by the panelists. Luckow and Delahunty [8] found that for probiotic blackcurrant juice the sensory characteristic was better than the control sample. Some other researchers $[28,34]$ also found similar results in case of mango and pineapple probiotic juice.

\section{Conclusion}

L. plantarum and L. fermentum were used to produce probiotic pineapple juice, and their ability to produce lactic acid and cell synthesis were checked. Both of them were grown well in pineapple juice at $37{ }^{\circ} \mathrm{C}$, and the viable counts reached over $10^{9} \mathrm{CFU} / \mathrm{mL}$ after $48 \mathrm{~h}$ of fermentation at $37{ }^{\circ} \mathrm{C}$. The results of the present study demonstrated that both $L$. plantarum and L. fermentum were able to survive in fermented juices with high acidity. Therefore, it could be advocated that pineapple juice could be exploited as a carrier for fermentation and delivery of probiotic lactic acid bacteria, and these probiotic-fortified fruit products could be used as a functional healthy beverage to promote better health and nutrition of the population. However, more extensive in vitro and in vivo studies are vital in order to authenticate the probiotic potential and safety of such cultures and fruit products based on these beneficial microbes before being endorsed for the better health and nutrition of society.

\section{References}

1. R. Fuller, J. Appl. Bacteriol. 66, 365 (1989).

2. M. Roberfroid, Am. J. Clin. Nutr. 71, 1682 (2000). https://doi.org/10.1093/ajcn/71.6.1682S

3. A. C. Ouwehand, S. Salminen, and E. Isolauri, AntonieVan Leeuwenhoek 82, 279 (2002). https://doi.org/10.1023/A:1020620607611

4. J. S. Salminen, M. Gueimonde, and E. Isolauri, J. Nutr. 135, 1294 (2005). https://doi.org/10.1093/jn/135.5.1294

5. M. Kumar, V. Verma, R. Nagpal, A. Kumar, S. K. Gautam, P. V. Behare, C. R. Grover, and P. K. Aggarwal, Gene, 490, 54 (2011). https://doi.org/10.1016/j.gene.2011.09.003

6. R. Nagpal, H. Yadav, A. K. Puniya, K. Singh, S. Jain, F. Marotta, Int. J. Probiotics Prebiotics 2, 75 (2007).

7. N. Zahra, M. Khan, Z. Mehmood, M. K. Saeed, I. Kalim, I. Ahmad, and K. A. Malik, J. Sci. Res. 10, 315 (2018). https://doi.org/10.3329/jsr.v10i3.37075

8. T. Luckow and C. Delahunty, Food Qual. Prefer. 15, 751 (2004). https://doi.org/10.1016/j.foodqual.2003.12.007

9. S. Parvez, K. A. Malik, S. A. Kang, and H. -Y. Kim, J. Appl. Microbiol. 100, 1171 (2006). https://doi.org/10.1111/j.1365-2672.2006.02963.x

10. J. Karovicova and Z. Kohajdova, Hort. Sci. (Prague) 30, 152 (2003). https://doi.org/10.17221/3878-HORTSCI

11. R. Nagpal, A. Kumar, and M. Kumar, Annu. Microbiol. 62, 1573 (2012). https://doi.org/10.1007/s13213-011-0412-5 
12. K. Y. Yoon, E. E. Woodams, and Y. D. Hang, Swis. Soc. Food Sci. Technol. 38, 73 (2004). https://doi.org/10.1016/j.lwt.2004.04.008

13. K. Y. Yoon, E. E. Woodams, and Y. D. Hang, Bioresour. Technol. 97, 1427 (2006). https://doi.org/10.1016/j.biortech.2005.06.018

14. B. T. Nguyen, E. Bujna, N. Fekete, A. T. M. Tran, J. M. Rezessy-Szabo, R. Prasad, and Q. D. Nguyen, Front. Nutr. 6, 54 (2019). https://doi.org/10.3389/fnut.2019.00054

15. J. White and S. Hekmat, Fermentation 4, 27 (2018). https://doi.org/10.3390/fermentation4020027

16. Z. E. Mousavi, S. M. Mousavi, S. H. Razavi, Z. Emam-Djomeh, and H. Kiani, World J. Microbiol. Biotechnol. 27, 123 (2011). https://doi.org/10.1007/s11274-010-0436-1

17. M. Dubios, K. A. Gilles, J. K. Hamilton, D. A. Roberts, and F. Smith, Anal. Chem. 28, 350 (1956). https://doi.org/10.1021/ac60111a017

18. A.O.A.C. Association of Official Analytical Chemists. $21^{\text {st }}$ Edition (Gaithersburg, Maryland, USA, 2019).

19. A. A. Hassan, M. M. A. Aly, and S. T. El Hadidie, World Appl. Sci. J. 19, 1367 (2012).

20. B. M. Walts, G. L. Ylimaki, L. E. Jeffrey, and L. G. Elias, Sensory Methods for Food Evaluation (IDRG, Ottawa, 1989), pp.6-9, 60-79.

21. SPSS, I. IBM SPSS Statistics base 20. Chicago, IL: SPSS Inc. (2011).

22. K. Y. Yoon, E. E. Woodams, and Y. D. Hang, J. Microbiol. 42, 315 (2004).

23. A. Nazarudeen, In. J. Trad. Knowl. 9, 394 (2010).

24. C. Batista, L. Barros, A. M. Carvalho, and I. C. F. R. Ferreira, Food Chem. Toxicol. 49, 1208 (2011). https://doi.org/10.1016/j.fct.2011.02.023

25. N. J. Gardner, T. Savard, P. Obermeier, G. Caldwell, and C. P. Champagne, Int. J. Food Microbiol. 64, 261 (2001). https://doi.org/10.1016/S0168-1605(00)00461-X

26. M. Tolonen, S. Rajaniemi, J. M. Pihlava, T. Johansson, P. Saris, and E. L. Ryhänen, Food Microbiol. 21, 167 (2004). https://doi.org/10.1016/S0740-0020(03)00058-3

27. A. Lourens-Hattingh and B. C. Viljoen, Int. Dairy J. 1, 1 (2001). https://doi.org/10.1016/S0958-6946(01)00036-X

28. M. A. Hossain, M. M. Hoque, M. H. Kabir, and M. Yasin, J. Eng. Res. Inn. Educ 1, (2019).

29. M. Gaanappriya, P. Guhankumar, V. Kiruththica, N. Santhiya, and S Anita, Int. J. Adv. Biotechnol. Res. 4, 72 (2013).

30. N. P. Shah, J. Dairy Sci. 83, 894 (2000). https://doi.org/10.3168/jds.S0022-0302(00)74953-8

31. V. Sharma and H. N. Mishra, Nutrafoods 12, 17 (2013). https://doi.org/10.1007/s13749-012-0050-y

32. N. Ishibashi, S. Shimamura, Food Technol. 47, 126 (1993). https://doi.org/10.1016/03088146(93)90167-E

33. N. P. Shah, W. E. V. Lankaputhra, M. Britz, and W. S. A. Kyle, Int. Dairy J. 5, 515 (1995). https://doi.org/10.1016/0958-6946(95)00028-2

34. B. A. Tayo and S. Akpeji, Fermentation 2, 20 (2016). https://doi.org/10.3390/fermentation2040020 